\title{
A biological tool for indicating hypoxia in coastal waters: calcareous walled-type to naked-type cysts of Scrippsiella trochoidea (Dinophyceae)
}

\author{
AKIRA ISHIKAWA ${ }^{1, *}$, Hiroaki WaKabAYASHI ${ }^{1, \uparrow} \&$ Young-OK KIM ${ }^{2}$ \\ ${ }^{1}$ Graduate School of Bioresources, Mie University, 1577 Kurima-machiya, Mie 514-8507, Japan \\ ${ }^{2}$ Marine Environmental and Climate Research Division, Korea Institute of Ocean Science and Technology, 49111 Busan, Repub- \\ lic of Korea \\ ${ }^{\dagger}$ Present address: Hydrographic and Oceanographic Department, Japan Coast Guard, Kasumigaseki, Chiyoda-ku, Tokyo 100- \\ 8932, Japan
}

Received 27 February 2019; Accepted 10 May 2019 Responsible Editor: Joon-Baek Lee

doi: $10.3800 /$ pbr. 14.161

\begin{abstract}
Scrippsiella trochoidea produces a calcareous walled cyst with spines during its life history. It has been recently reported that the calcareous wall can be decalcified under acidified conditions in coastal areas linked to hypoxia caused by bacterial activities. In this study, in order to determine whether the calcareous cysts can be a biological tool for indicating an in situ hypoxic environment, the morphology of $S$. trochoidea cysts in the surface sediments of Ise Bay, Japan, was examined in relation to dissolved oxygen concentrations in the bottom water. The surface sediments were collected from the inner to outer parts of the bay in May 2014 and June 2018. The living cysts of S. trochoidea were counted separately into two morphotypes: cyst with calcareous wall (calcareous walled-type cyst) and without the wall (naked-type cyst). The proportions (\%) of naked-type cyst abundance in the total living cyst population showed an increasing tendency in the hypoxic environment of the inner and central parts of Ise Bay, but not in the normoxic environment at the mouth. This result supports the supposition that the naked-type cyst of $S$. trochoidea can be used as a biological indicator for the assessment of hypoxia in coastal areas.
\end{abstract}

Key words: Biological indicator, DO, hypoxic condition, $\mathrm{pH}$, Scrippsiella trochoidea cyst

\section{Introduction}

Eutrophication is now widespread in the coastal waters and embayments of the world (Howarth et al. 2002) and usually causes hypoxia by bacterial activities (i.e. decomposition of organic matter) when the water column is stratified. Such hypoxic waters strongly decrease the survivability of benthic organisms and eventually damage the ecosystem (e.g. Hossain \& Sekiguchi 1996, Suzuki et al. 1998, Diaz \& Rosenberg 2008, Sone et al. 2017).

During the process of decomposition of organic matter by bacteria, oxygen is consumed and carbon dioxide $\left(\mathrm{CO}_{2}\right)$ is generated as a resultant product. Therefore, the more organic matter that is decomposed, the more $\mathrm{CO}_{2}$ that is generated. This, in turn, results in lowering $\mathrm{pH}$ by

* Corresponding author: Akira Ishikawa; E-mail, ishikawa@bio.mie-u. ac.jp increasing $\mathrm{H}^{+}$coupled with the accumulation of $\mathrm{CO}_{2}$. In addition, further $\mathrm{CO}_{2}$ is generated by anaerobic bacterial activities under hypoxic conditions, such as nitrate reduction and methane fermentation, leading to an acceleration in $\mathrm{pH}$ decrease. Thus, eutrophication consequently causes an increase in $\mathrm{CO}_{2}$ and the resultant water acidification (Taguchi \& Fujiwara 2010). Water acidification has also been suggested to be a great threat for calcifying organisms such as coral, scallops, oysters and some plankton (Orr et al. 2005, Hoegh-Guldberg et al. 2007, Talmage \& Gobler 2009).

Many dinoflagellate species produce resting cysts during their life history (e.g. Dale 1983, Matsuoka \& Fukuyo 2000). Scrippsiella trochoidea (Stein) Loeblich III is also a cyst-forming species and is one of the most widely distributed marine dinoflagellates in the neritic areas of the world's oceans (e.g. Wall et al. 1970, Godhe et al. 2000, Ishikawa \& Taniguchi 2000, Kim \& Han 2000, Wang et al. 


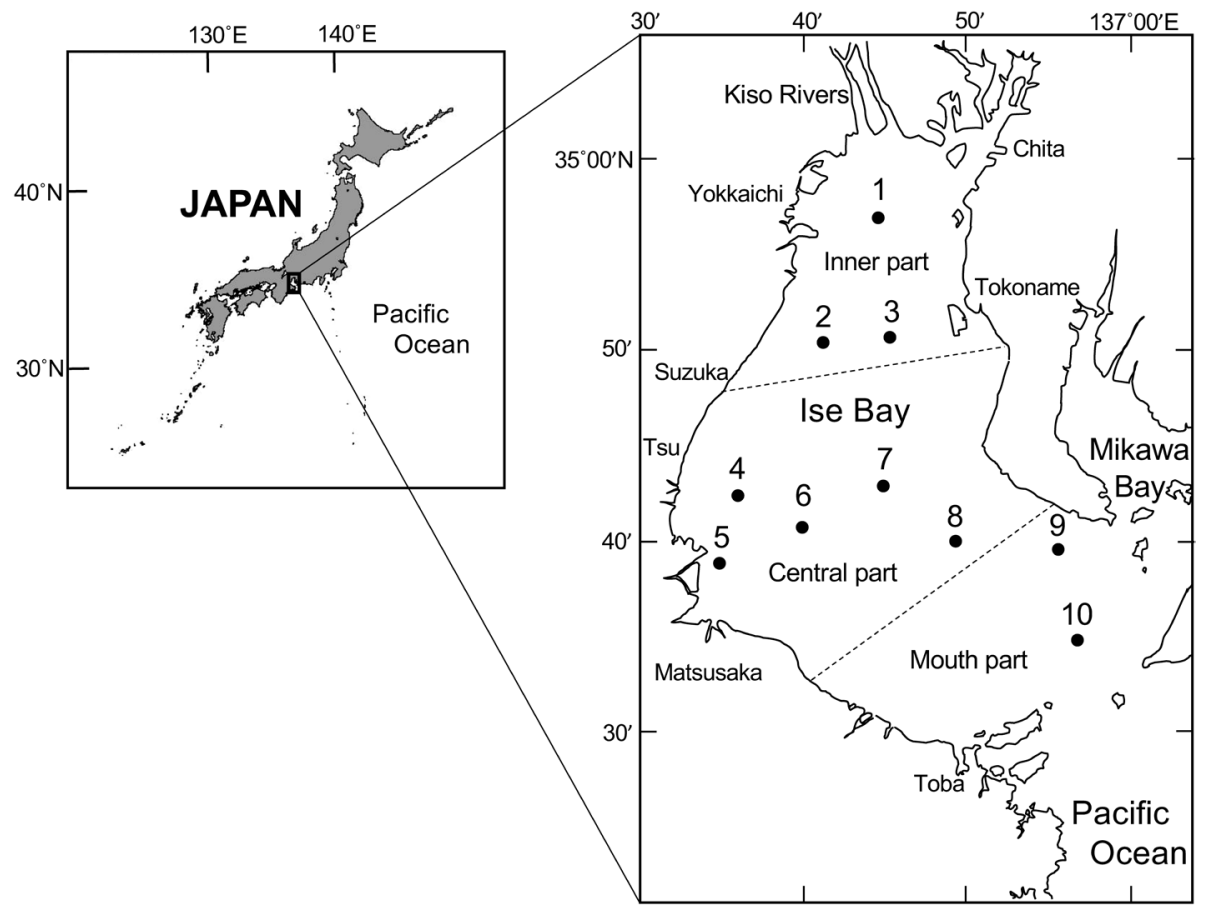

Fig. 1. Locations of sampling stations in Ise Bay, central part of Japan.

2004). It is well known that this species forms a cyst with calcareous spines. However, another type of cyst without calcareous spines was also observed in the natural surface sediments of a Chinese eutrophied coastal area (Wang et al. 2007). Shin et al. (2013) also detected cysts without calcareous spines in the eutrophied embayment of Gamak Bay in Korea: they described the cysts with and without the spines as spiny-type and naked-type cysts, respectively. Morphological change from spiny-type to naked-type cysts was induced in a culture medium acidified through laboratory manipulation (Shin et al. 2013). Therefore, Shin et al. (2013) suggested the possibility that naked-type cysts could be an indicator of hypoxic and acidic environments due to eutrophication.

Ise Bay is a large semi-enclosed eutrophied embayment located in the central part of Japan (Fig. 1). Cysts of $S$. trochoidea are the dominant cysts in the sediments of the bay (A Ishikawa, unpublished data). Therefore, we tried to confirm the suggestion by Shin et al. (2013) that S. trochoidea cysts could be a biological indicator of hypoxic bottom conditions in eutrophied embayments.

\section{Materials and Methods}

\section{Study area}

The bottom topography in the bay is a basin in shape and the average depth is ca. $20 \mathrm{~m}$. The mouth of Ise Bay is relatively narrow and opens to the North Pacific Ocean. Its eastern side connects to Mikawa Bay. Kiso Rivers in the innermost part of the bay discharge freshwater, produc-
Table 1. Position and depth at sampling stations in Ise Bay in May 2014 and June 2018.

\begin{tabular}{|c|c|c|}
\hline Station & Position & Depth (m) \\
\hline 1 & $34^{\circ} 57.2^{\prime} \mathrm{N} \quad 136^{\circ} 44.0^{\prime} \mathrm{E}$ & 24 \\
\hline 2 & $34^{\circ} 50.3^{\prime} \mathrm{N} \quad 136^{\circ} 41.2^{\prime} \mathrm{E}$ & 25 \\
\hline 3 & $34^{\circ} 50.6^{\prime} \mathrm{N} \quad 136^{\circ} 45.2^{\prime} \mathrm{E}$ & 33 \\
\hline 4 & $34^{\circ} 43.1^{\prime} \mathrm{N} \quad 136^{\circ} 35.8^{\prime} \mathrm{E}$ & 24 \\
\hline 5 & $34^{\circ} 38.9^{\prime} \mathrm{N} \quad 136^{\circ} 34.8^{\prime} \mathrm{E}$ & 19 \\
\hline 6 & $34^{\circ} 40.7^{\prime} \mathrm{N} \quad 136^{\circ} 39.8^{\prime} \mathrm{E}$ & 33 \\
\hline 7 & $34^{\circ} 43.0^{\prime} \mathrm{N} \quad 136^{\circ} 44.7^{\prime} \mathrm{E}$ & 37 \\
\hline 8 & $34^{\circ} 40.2^{\prime} \mathrm{N} \quad 136^{\circ} 48.7^{\prime} \mathrm{E}$ & 36 \\
\hline 9 & $34^{\circ} 39.8^{\prime} \mathrm{N} \quad 136^{\circ} 55.6^{\prime} \mathrm{E}$ & 22 \\
\hline 10 & $34^{\circ} 35.2^{\prime} \mathrm{N} \quad 136^{\circ} 56.8^{\prime} \mathrm{E}$ & 56 \\
\hline
\end{tabular}

ing the estuarine circulation that transports low salinity upper water from the inner towards the mouth part, and conversely allows the intrusion of vertically mixed water from the mouth to the inner part of the bay, under the pycnocline (Fujiwara et al. 2002, Fujiwara 2007a, b). During the period from April to October (warm season), the mixed water from the mouth lies at mid-depths and the bottom cold water remains in the bay. A hypoxic environment usually develops in the bottom isolated cold water during this period (Fujiwara et al. 2002, Fujiwara 2007a, b).

\section{Sediment sampling}

Sediment sampling was carried out at 10 sites (Stns. 1-10) in Ise Bay during the SE14-04 cruise of the T/S Seisui Maru (Mie University) from 26 to 27 May 2014 and 

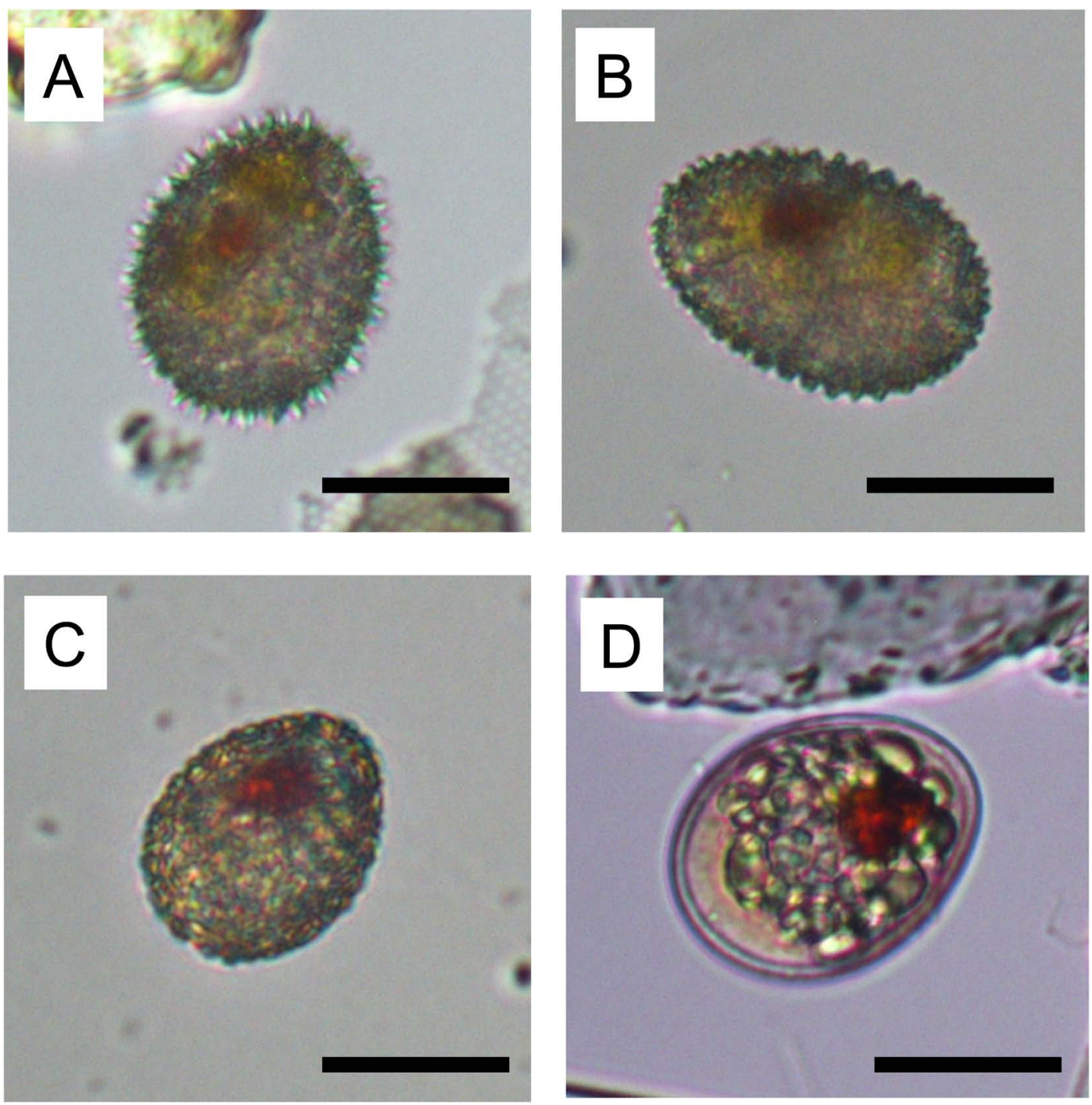

Fig. 2. Light microscopy photographs of Scrippsiella trochoidea cysts with (A) typical spines, (B) short spines, (C) only wall and (D) without wall. (A), (B) and (C) are categorized as calcareous walled-type cysts and (D) as a naked-type cyst. Scale bars represent $20 \mu \mathrm{m}$.

also at 6 sites (Stns. 1, 3, 5, 7, 8, 10) during the SE18-07 cruise from 10 to 11 June 2018 (Fig. 1, Table 1). Stns. 1-3 were located in the inner part and Stns. 4-8 in the central part, Stns. 9 and 10 in the mouth part of the bay, respectively. Three sediment core samples were collected with a gravity core sampler at each site. The top $3 \mathrm{~cm}$ of each core was then sliced off and placed into a sample bottle. These samples were brought back to the laboratory and stored at $4^{\circ} \mathrm{C}$ in the dark until sediment treatment.

\section{Sediment treatment and cyst observation}

The sediment samples were treated according to a modification of the method described by Matsuoka \& Fukuyo (2000). Concretely, $2 \mathrm{~g}$ of wet sediment was suspended in ca. $50 \mathrm{ml}$ of filtered seawater and sonicated for a minute to release the cysts from the aggregated materials. Then, the suspension was sieved through a $125 \mu \mathrm{m}$ mesh onto a $20 \mu \mathrm{m}$ mesh screen. The sieved fraction (20 to $125 \mu \mathrm{m}$ ) was resuspended in $20 \mathrm{~mL}$ of the filtered seawater. Thus, the final suspension, at a concentration of $0.1 \mathrm{~g} \mathrm{~mL}^{-1}$ of the original wet sediment, was obtained and fixed immediately by adding borax-buffered formaldehyde solution at a final concentration of $1 \%$. A 0.5 or $0.25 \mathrm{~mL}$ aliquot of the fixed suspension was spread over a Sedgewick-Rafter counting chamber, adding $0.5 \mathrm{~mL}$ of filtered seawater. The living cysts of Scrippsiella trochoidea, which contained a red body, were counted under a microscope (NIKON OPTIPHOT) at $100 \times$ or $200 \times$ (usually $100 \times$ ). The cysts were counted and separated into two morphotypes based on their external morphology; calcareous walled-type and naked-type cysts. Calcareous walled-type cysts included three sub-types: typical spines (Fig. 2A), short spines (Fig. 2B) and only calcareous wall (no spines) (Fig. 2C). The naked-type cyst is transparent because its outer calcareous wall is totally lost (Fig. 2D). All counts were done in triplicate and mean densities (cysts $\mathrm{g}^{-1}$ of wet sediment) 
were calculated for each sample. The proportion (\%) of naked-type cysts in the total cyst (calcareous walled-type plus naked-type cysts) abundances in each sample was also estimated.

In the sediment of Ise Bay, the cysts of other Scrippsiella spp., such as $S$. precaria Montresor \& Zingone and $S$. cf. trifida, were also observed. However, their abundances were negligible so that those species were not enumerated.

\section{Dissolved oxygen concentration and $\mathrm{pH}$ data}

Vertical hydrographic data on the water column of Ise Bay has been provided officially from the Mie Prefecture Fisheries Research Institute (Data available at http://www. pref.mie.lg.jp/suigi/hp/79877017487.htm). The data is updated monthly based on shipboard oceanographic observations at 16 sites in the bay. All sampling sites in this study (Fig. 1) coincided with the corresponding sites where the dissolved oxygen concentration (hereafter referred as DO) ( $\mathrm{mg} \mathrm{L}^{-1}$ ) and $\mathrm{pH}$ data were collected. The values recorded near the bottom ( $1 \mathrm{~m}$ above the surface sediment) at each site in the previous years (i.e. the years 2013 and 2017) of sediment sampling in this study were selected as the bottom $\mathrm{DO}$ and $\mathrm{pH}$ data.

\section{Results}

\section{Bottom DO and pH}

Bottom DO showed a clear temporal pattern (Fig. 3). DO decreased from April/May and was almost always below $4 \mathrm{mg} \mathrm{L}^{-1}$ in May/June. Thereafter, DO remained at low levels during the warm season (from June/July to September/October). This trend was remarkable at Stns. 1-8 in the inner and central parts of the bay but not at Stns. 9 and 10 in the mouth. The DO values averaged between May and October in 2013 and 2017 at each site in the inner and central parts (Stns. 1-8) were in the range of $1.2-3.7 \mathrm{mg} \mathrm{L}^{-1}$ and $1.7-2.7 \mathrm{mg} \mathrm{L}^{-1}$ for these respective years, while those in the mouth part were 5.7 (at St. 9) and $6.0 \mathrm{mg} \mathrm{L}^{-1}$ (at St. 10) in 2013 and $5.3 \mathrm{mg} \mathrm{L}^{-1}$ (at St. 10) in 2017 (Fig. 4A). The minimum values recorded at each site in the inner and the central parts in 2013 and 2017 were in
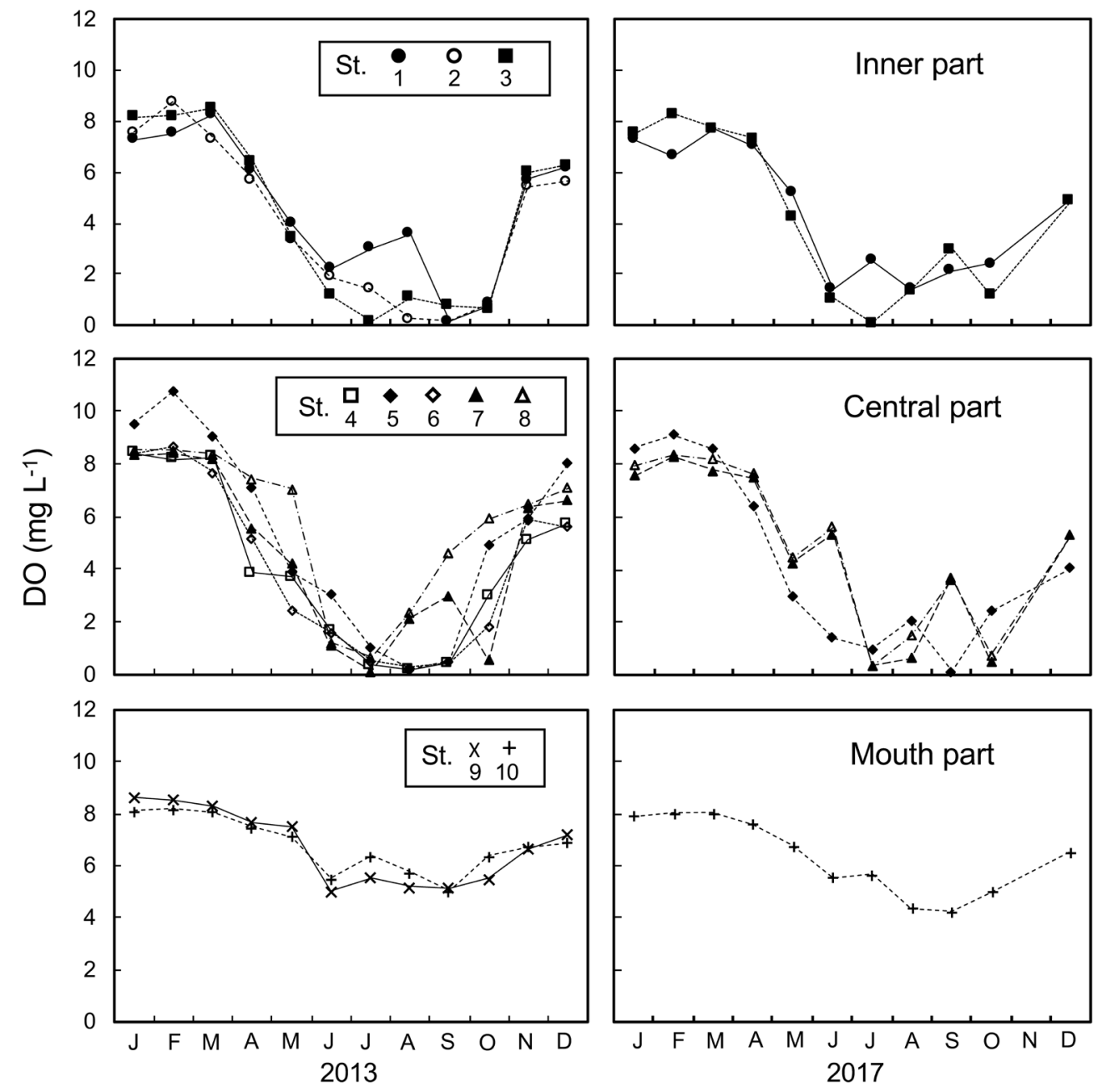

Fig. 3. Temporal changes in the bottom DO concentration at the sampling stations in Ise Bay in 2013 and 2017 (each previous year of the sediment sampling years in 2014 and 2018). 


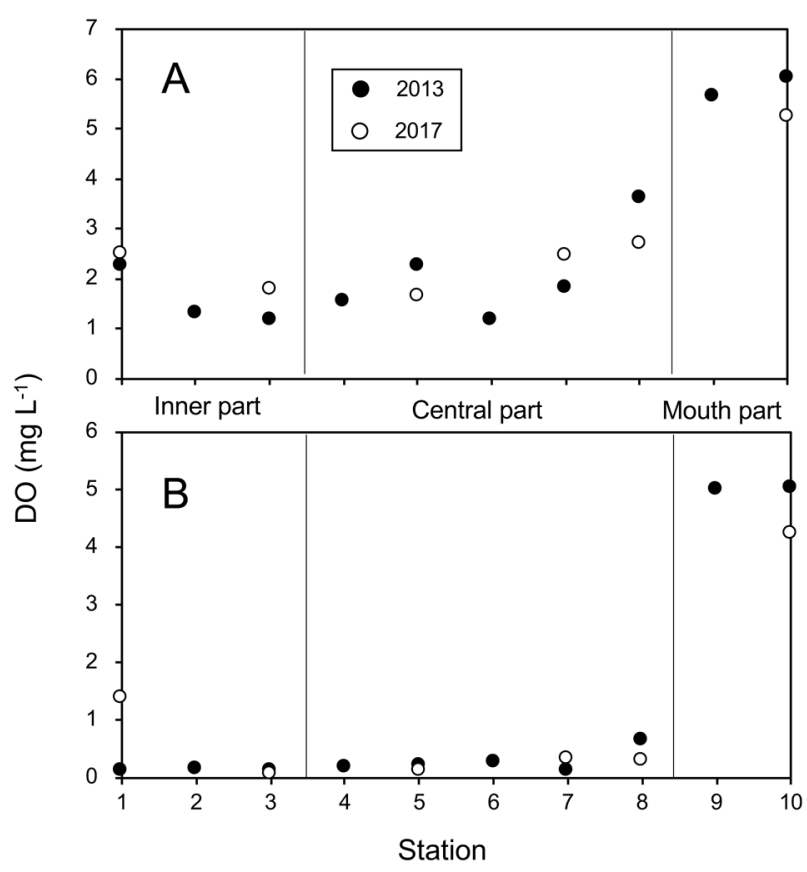

Fig. 4. Spatial distribution of (A) the bottom DO concentration averaged over the period from May to October and (B) the minimum DO concentration at the sampling stations in 2013 and 2017.

the range of $0.1-0.7 \mathrm{mg} \mathrm{L}^{-1}$ and $0.1-1.4 \mathrm{mg} \mathrm{L}^{-1}$ for these respective years, while those in the mouth part were 5.0 (at St. 9) and $5.1 \mathrm{mg} \mathrm{L}^{-1}$ (at St. 10) in 2013 and $4.3 \mathrm{mg} \mathrm{L}^{-1}$ (at St. 10) in 2017 (Fig. 4B).

Bottom pH values in 2013 and 2017 at the sampling sites were lower during the period from May to October, which was a similar trend to the DO temporal change (Fig. 5). Lower $\mathrm{pH}$ values were remarkable at Stns. 1-8 in the inner and central parts of the bay but not at Stns. 9 and 10 in the mouth part. Minimum values of 7.7 were recorded at Stns. 3, 7 and 8 in June or July 2013 and also at the same stations in July and/or August 2017.

To analyze the relationship between $\mathrm{DO}$ and $\mathrm{pH}$ in Ise Bay, the whole data for bottom DO in 2013 and 2017 recorded at all sites (i.e. 16 sites) by the Mie Prefecture Fisheries Research Institute were plotted against those of bottom $\mathrm{pH}$ (Fig. 6). A highly significant positive relationship $(r=0.91, n=352, p<0.01$ ) was found between bottom DO and $\mathrm{pH}$.

\section{Abundances and proportions of cysts in the sediments}

The living cysts of Scrippsiella trochoidea were widely distributed over density ranges of 653 to 1,433 cysts $\mathrm{g}^{-1}$ and 753 to 1,440 cysts $\mathrm{g}^{-1}$ at the study sites in 2014 and 2018, respectively (Fig. 7A, C). Naked-type cysts in the living cyst population were always found at all sites and their relative abundances were from 2 to $27 \%$ and from 1 to $22 \%$ in 2014 and 2018, respectively (Fig. 7B, D).

\section{Relationship between DO and proportions of naked- type cysts in the sediment}

The proportion of naked-type cysts of Scrippsiella trochoidea at each site in each year was plotted against the DO values averaged between May and October (Fig. 8A) and the minimum DO values (Fig. 8B). There was a spatial difference in the relationship (Fig. 8A, B). Relatively higher proportions of the naked-type cysts were recorded in the hypoxic environments at Stns. 2 and 3 in the inner part of Ise Bay and at Stns. 4 and 5, which were close to the western coast. In contrast, lower proportions of nakedtype cysts in the normoxic bottom water occurred at Stns. 9 and 10 in the mouth of the bay. At Stns. 6, 7 and 8 in the central part, where the proportions of naked-type cysts were relatively low, the DO average varied between hypoxic and normoxic levels (Fig. 8A). Overall, the proportions of naked-type cysts in the central part (Stns. 4-8) changed over a wide range (Fig. 8A, B). In these relationships, it was notable that the relatively higher proportions $>14 \%$ were always recorded in the narrow ranges of $\mathrm{DO}$ values that averaged 1.3-2.3 $\mathrm{mg} \mathrm{L}^{-1}$ (Fig. 8A) and when the DO values were low at $0.1-0.2 \mathrm{mg} \mathrm{L}^{-1}$ (Fig. 8B).

\section{Discussion}

\section{Bottom DO and pH}

In this study, the timing of occurrence of the hypoxic bottom water observed in the inner and central parts of Ise Bay from May to October (Fig. 3) coincided with the intrusion timing of the mixed water from the bay mouth into the mid layer under the upper water by estuarine circulation (Fujiwara et al. 2002, Fujiwara 2007a, b). It is reconfirmed in this study that bottom water being overlaid by the intruding water in the mid layer might lead to development of an hypoxic environment.

The temporal change of $\mathrm{pH}$ in the bottom water of the bay (Fig. 5) was similar to that of DO (Fig. 3). It should be noted that a highly significant positive relationship was found between bottom DO and pH (Fig. 6). Similar corelationships were also reported from other semi-enclosed sea areas, such as Harima Sound, the Seto Inland Sea of Japan (Taguchi \& Fujiwara 2010), Gamak Bay on the southern coast of Korea (Shin et al. 2013), Puget Sound in a large estuary complex in the U.S. Pacific Northwest (Feely et al. 2010), and the Skagerrak-Baltic Sea region (Charrieau et al. 2018). These indicate that it may be a ubiquitous phenomenon in eutrophied sea areas that bottom waters are acidified by increasing $\mathrm{CO}_{2}$ followed by degradation of organic matter.

\section{Morphological changes from calcareous walled-type to naked-type cysts in the sediment}

According to Shin et al. (2013), the dissolution of the calcareous spines of Scrippsiella trochoidea cysts begins 

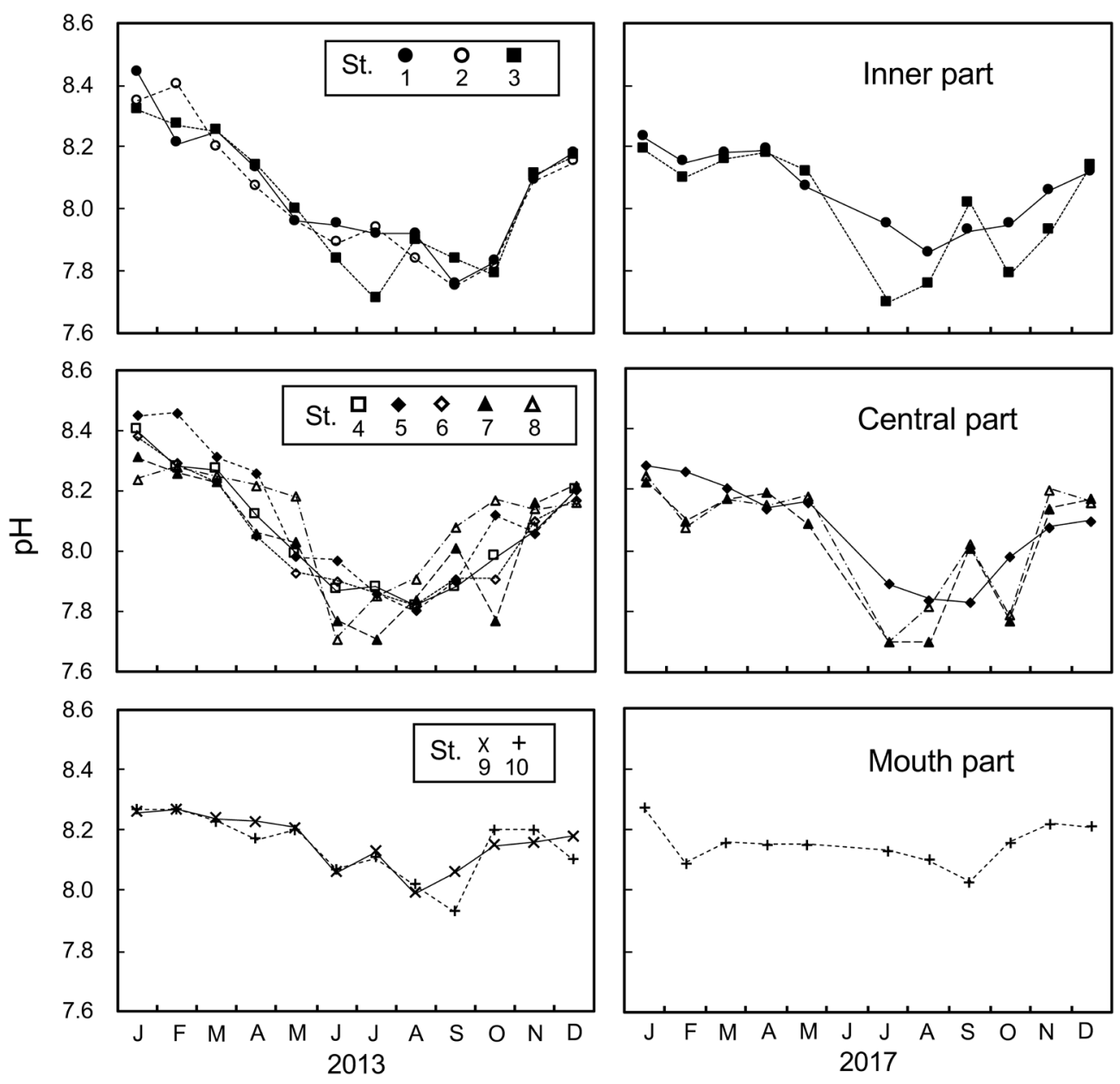

Fig. 5. Temporal changes in the bottom $\mathrm{pH}$ at the sampling stations in Ise Bay in 2013 and 2017 (each previous year of the sediment sampling years in 2014 and 2018).

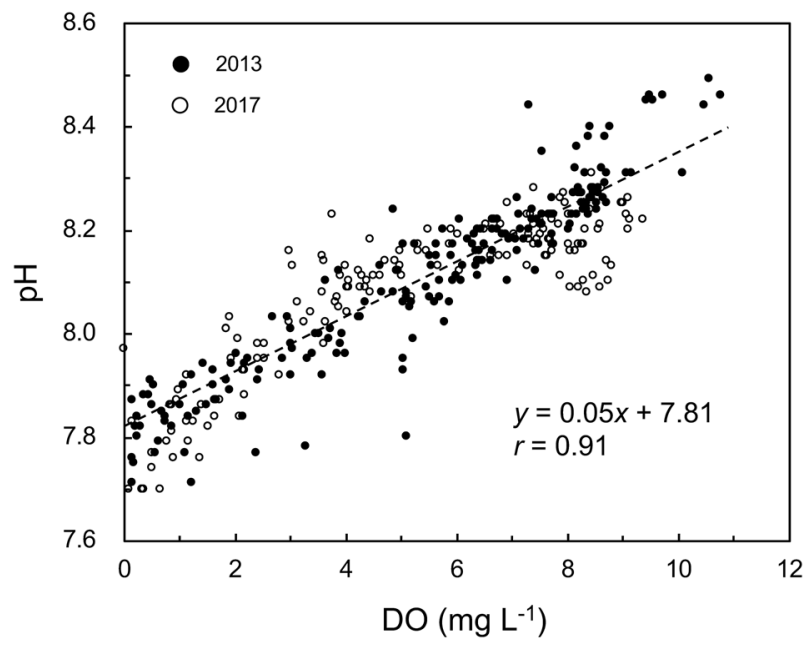

Fig. 6. Relationship between the bottom DO concentrations and $\mathrm{pH}$ in Ise Bay during the whole years of 2013 and 2017. All of the data obtained monthly at 16 sites by the Mie Prefecture Fisheries Research Institute were plotted. to occur below $\mathrm{pH} 7.39$, which is a value lower than that of the minima (i.e. $\mathrm{pH}$ 7.7) recorded in the bottom water of Ise Bay in 2013 and 2017 (Fig. 5). This indicates that even this minimum level of $\mathrm{pH}$ does not cause dissolution of calcareous spines. However, DO levels could be much lower at the sediment-water interface under strongly stratified conditions in the water column and also in the upper sediment layers where the cysts were actually distributed. Therefore, the $\mathrm{pH}$ levels at the surface sediment could become much lower than in the bottom water (see Zhang et al. 2010). Shin et al. (2013) reported that $\mathrm{pH}$ level in the sediment was significantly lower (ca. 6.8) than that in the bottom waters (ca. 7.6) at a eutrophied area in Gamak Bay. Such acidic conditions in the sediment are enough to dissolve the calcareous spines of cysts.

Shin et al. (2013) also reported that living S. trochoidea cysts captured by a sediment trap deployed weekly in Gamak Bay were mostly ones with calcareous spines (spiny-type cysts), indicating there was a small number of naked-type cysts in the trap samples. However, the trap samples were stored for three months at ambient temperatures (ca. 15 to $20^{\circ} \mathrm{C}$ ) in the laboratory (YO Kim, personal 

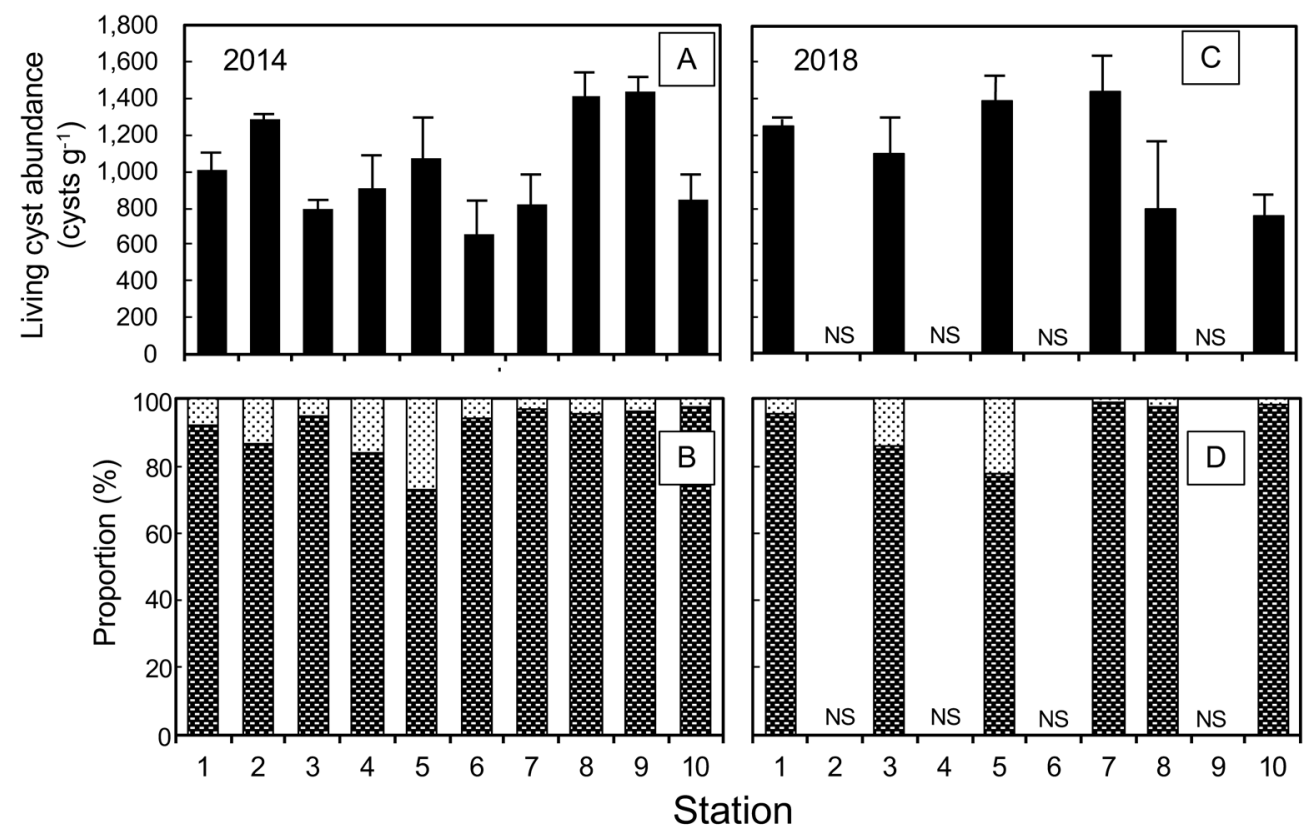

Station

圈 Calcareous walled-type Naked-type

Fig. 7. Spatial variations in (A) the total living cyst abundance of Scrippsiella trochoidea and (B) the proportion of calcareous walled-type and naked-type cysts compared to the total living cyst abundance in Ise Bay in May 2014 and the same panels for (C) and (D) as in (A) and (B) but in June 2018. Bars in (A) and (C) represent +SD. NS in (C) and (D) denotes that no sample was collected.

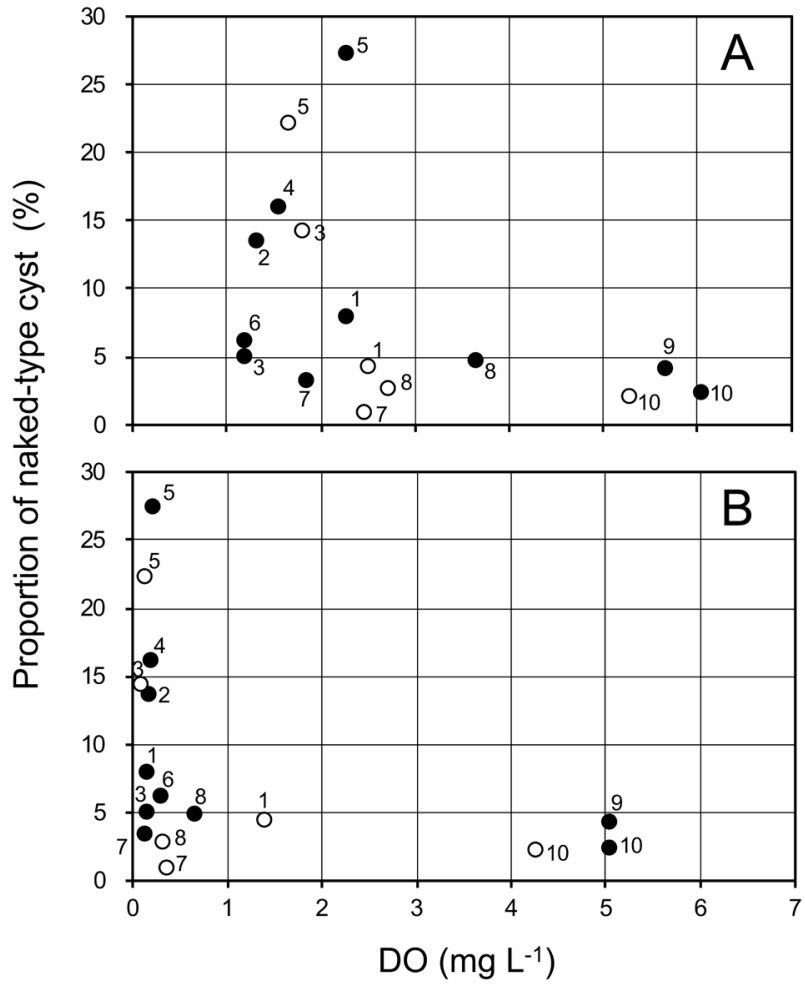

Fig. 8. Relationships between proportion of naked-type cysts of Scrippsiella trochoidea compared to the total living cyst abundance at each sampling site in May 2014 (O) and June $2018(\bigcirc)$ and both, (A) the bottom DO concentration averaged over the period from May to October and (B) the minimum DO concentration at each corresponding site in 2013 and 2017. Numbers next to each circle represent the station numbers. communication), so it is assumed that the organic matter deposited in the trap sample probably decayed due to bacterial activity and with the passing of time an acidic environment would have been generated in parts of the sample, which could have caused the change of a small number of spiny-type cysts to naked-type ones. This indicates that dissolution of the calcareous spines of cysts does not occur during the sinking process to the bottom sediments after the cysts are newly produced as intact cysts. Therefore, it can be supposed that the dissolution of calcareous spines (and walls) was due to the acidic environment they experienced after deposition into the bottom sediments.

\section{Scrippsiella trochoidea cysts as an indicator of hypoxic waters}

Although the naked-type cyst of Scrippsiella trochoidea was always found at all sampling sites, the proportion of naked cysts to total living cyst abundance varied spatially depending on the site in both 2014 and 2018 (Fig. $7 \mathrm{~B}, \mathrm{D})$. An analysis of the relationship between the proportions of naked-type to total cysts at each site in each year and the DO values, averaged from May to October, showed that the proportions tended to increase in the hypoxic environments of the inner and central parts of Ise Bay, but remained at lower levels in the normoxic environment at the mouth of the bay (Fig. 8A). This finding mirrored the results for the relationship between the proportions and the minimum DO values (Fig. 8B). It should be noted that relatively higher proportions $(>14 \%)$ of na- 
ked-type cysts were recorded when average DO was lower than $2.3 \mathrm{mg} \mathrm{L}^{-1}$ (Fig. 8A) and when the minimum DO was below $0.2 \mathrm{mg} \mathrm{L}^{-1}$ (Fig. 8B). Accordingly, specific sites in coastal areas where the proportion of naked-type cysts to total living cysts exceeds $14 \%$ could be considered to be hypoxic environments during the warm season (May to October). Thus, this study supports the possibility that cysts of $S$. trochoidea can be used as biological indicators of hypoxic condition in natural seafloor environments.

The criteria of survivability for marine organisms affected by DO levels is, for example, defined by the Aichi Fisheries Research Institute, as follows: a bad effect on fishes and crustaceans occurs at DO values of 2.0-4.0 $\mathrm{mg} \mathrm{L}^{-1}$, survival is difficult for shellfish and benthic fishes at DO values of $0.8-2.0 \mathrm{mg} \mathrm{L}^{-1}$, and for all benthic organisms at DO values of $<0.8 \mathrm{mg} \mathrm{L}^{-1}$ (https://www.pref. aichi.jp/soshiki/suisanshiken/0000009720.html). Following these criteria and using the values for the proportion of naked-type cysts to total cysts obtained in May 2014 and June 2018, sites where the proportion exceeded $14 \%$ could be considered to be "dead zones", where severe hypoxia occurs. Consequently, the cysts of $S$. trochoidea may act as a biological indicator enabling the assessment of the survivability of environments for marine organisms, and they may be a more sensitive indicator than other organisms with calcified shells.

Scrippsiella trochoidea is widely distributed throughout the world's neritic oceans (e.g. Wall et al. 1970, Godhe et al. 2000, Ishikawa \& Taniguchi 2000, Kim \& Han 2000, Wang et al. 2004). Due to its cosmopolitan biogeography and high growth ability of vegetative cells, the cyst of $S$. trochoidea is one of the dominant components of cyst assemblages in the coastal sediments of the world. Although this species is also known to be a red tide-causing harmful species (Hallegraeff 1993), this study proposes that investigating the cysts might be a useful approach for the management of dead zones that have expanded due to recent coastal eutrophication and hypoxia. However, in this study, data on the proportion of naked-type cysts vs total cysts was limited only to Ise Bay in May 2014 and June 2018. The proportion of naked-type cysts could vary depending on the season as well as the year because the numbers of newly deposited intact cysts (i.e. typical type cysts with spines) entering the sediments after blooming of vegetative cells changes, and morphological changes in the intact cysts over time also occurs in the sediment. Indeed, Shin et al. (2013) showed that the proportion of naked-type cysts changed seasonally in the sediments of Gamak Bay, with a higher ratio in winter and spring. Blooming of $S$. trochoidea in Ise Bay usually occurs from spring to autumn (A Ishikawa, unpublished data). This implies that the newlyformed intact cysts are deposited in large numbers into the sediment during these seasons and then relative abundances change in complex ways. In addition, bottom current dynamics might affect cyst distributions. Furthermore, benthic predators feed on cysts, possibly dissolving their calcareous walls during the digestion process and excreting them as naked-type cysts. Therefore, in order to establish a precise and general methodology for the assessment of hypoxic conditions utilizing S. trochoidea cysts, further studies are necessary in various eutrophied embayments, in different seasons and years, and considering the physical and biological environments as well as chemical conditions in the bottom waters or sediments.

\section{Acknowledgements}

We are grateful to the captain and crew of the T/S Seisui Maru of Mie University and our colleagues at the university for their support at sea. We also thank Mie Prefecture Fisheries Research Institute for providing valuable oceanographic data concerning Ise Bay. This work was partially supported by a Grant-in-Aid for Scientific Research (C) from the Japan Society for the Promotion of Science (JSPS) (KAKENHI; Nos. 25450256 and 16K07823) and by the Research Foundation of Korea (NRF-2016M1A5A1027457).

\section{References}

Aichi Fisheries Research Institute. Available at: https://www. pref.aichi.jp/soshiki/suisanshiken/0000009720.html (accessed on 10 May 2018) (in Japanese)

Charrieau LM, Filipsson HL, Ljung K, Chierici M, Knudsen KL, Kritzberg E (2018) The effects of multiple stressors on the distribution of coastal benthic foraminifera: A case study from the Skagerrak-Baltic Sea region. Mar Micropaleontol 139: 42-56.

Dale B (1983) Dinoflagellate resting cysts: “benthic plankton”. In: Survival Strategies of the Algae (ed Fryxell GA). Cambridge University Press, Cambridge, pp. 69-136.

Diaz RJ, Rosenberg R (2008) Spreading dead zones and consequences for marine ecosystems. Science 321: 926-929.

Feely RA, Alin SR, Newton J, Sabine CL, Warner M, Devol A, Krembs C, Maloy C (2010) The combined effects of ocean acidification, mixing, and respiration on $\mathrm{pH}$ and carbonate saturation in an urbanized estuary. Estuar Coast Shelf Sci 88: 442-449.

Fujiwara T (2007a) Estuarine circulations in river-mouth areas and enclosed coastal seas. Bull Coast Oceanogr 44: 95-106. (in Japanese with English abstract)

Fujiwara T (2007b) Ise wan no hin-sanso suikai wa donoyouni site dekiruka [Generation mechanism of hypoxic water mass in Ise Bay]. Kaiyo Monthly 39: 5-8. (in Japanese)

Fujiwara T, Takahashi T, Kasai A, Sugiyama Y, Kuno M (2002) The role of circulation in the development of hypoxia in Ise Bay, Japan. Estuar Coast Shelf Sci 54: 19-31.

Godhe A, Karunasagar I, Karunasagar I, Karlson B (2000) Dinoflagellate cysts in recent marine sediments from SW India. Bot Mar 43: 39-48.

Hallegraeff GM (1993) A review of harmful algal blooms and their apparent global increase. Phycologia 32: 79-99.

Hoegh-Guldberg O, Mumby PJ, Hooten AJ, Steneck RS, Green- 
field P, Gomez E, Harvell CD, Sale PF, Edwards AJ, Caldeira K, Knowlton N, Eakin CM, Iglesias-Prieto R, Muthiga N, Bradbury RH, Dubi A, Hatziolos ME (2007) Coral reefs under rapid climate change and ocean acidification. Science 318: 1737-1742.

Hossain M, Sekiguchi H (1996) Influences of oxygen-poor water on megabenthos communities in Ise Bay, central Japan. Bull Jpn Soc Fish Oceanogr 60: 237-243.

Howarth RW, Sharpley A, Walker D (2002) Sources of nutrient pollution to coastal waters in the United States: implications for achieving coastal water quality goals. Estuaries 25: 656-676.

Ishikawa A, Taniguchi A (2000) Vegetative cell and cyst assemblages of armored dinoflagellates in Onagawa Bay, northeast Japan. Plankton Biol Ecol 47: 12-22.

Kim YO, Han MS (2000) Seasonal relationships between cyst germination and vegetative population of Scrippsiella trochoidea (Dinophyceae). Mar Ecol Prog Ser 204: 111-118.

Matsuoka K, Fukuyo Y (2000) Technical Guide for Modern Dinoflagellate Cyst Study. WESTPAC-HAB/WESTPAC/IOC 2000, Tokyo, 29 pp.

Mie Prefecture Fisheries Research Institute. Available at: http:// www.pref.mie.lg.jp/suigi/hp/79877017487.htm (accessed on 5 April 2018) (in Japanese)

Orr JC, Fabry VJ, Aumont O, Bopp L, Doney SC, Feely RA, Gnanadesikan A, Gruber N, Ishida A, Joos F, Key RM, Lindsay K, Maier-Reimer E, Matear R, Monfray P, Mouchet A, Najjar RG, Plattner GK, Rodgers KB, Sabine CL, Sarmiento JL, Schlitzer R, Slater RD, Totterdell IJ, Weirig MF, Yamanaka Y, Yool A (2005) Anthropogenic ocean acidification over the twenty-first century and its impact on calcifying organisms. Nature 437: 681-686.

Shin HH, Jung SW, Jang MC, Kim YO (2013) Effect of pH on the morphology and viability of Scrippsiella trochoidea cysts in the hypoxic zone of a eutrophied area. Harmful Algae 28:
$37-45$.

Sone R, Waku M, Yamada S, Suzuki T, Takabe T (2017) Spatiotemporal dynamics and mortality of mega-benthos in relation to the development of hypoxia in an inner bay: a model study in Mikawa Bay, Japan. Bull Jpn Soc Fish Oceanogr 81: 230244. (in Japanese with English abstract)

Suzuki T, Aoyama H, Kai M, Imao K (1998) Effect of dissolved oxygen deficiency on a shallow benthic community in an embayment. Oceanogr Jpn 7: 223-236. (in Japanese with English abstract)

Taguchi F, Fujiwara T (2010) Carbon dioxide stored and acidified low oxygen bottom waters in coastal seas, Japan. Estuar Coast Shelf Sci 86: 429-433.

Talmage SC, Gobler CJ (2009) The effects of elevated carbon dioxide concentrations on the metamorphosis, size, and survival of larval hard clams (Mercenaria mercenaria), bay scallops (Argopecten irradians), and Eastern oysters (Crassostrea virginica). Limnol Oceanogr 54: 2072-2080.

Wall D, Guillard RRL, Dale B, Swift E, Watabe N (1970) Calcitic resting cysts in Peridinium trochoideum (Stein) Lemmermann, an autotrophic marine dinoflagellate. Phycologia 9: $151-156$.

Wang Z, Matsuoka K, Qi Y, Chen J (2004) Dinoflagellate cysts in recent sediments from Chinese coastal waters. Mar Ecol 25: 289-311.

Wang Z, Qi Y, Yang Y (2007) Cyst formation: an important mechanism for the termination of Scrippsiella trochoidea (Dinophyceae) bloom. J Plankton Res 29: 209-218.

Zhang J, Gilbert D, Gooday AJ, Levin L, Naqvi SWA, Middelburg JJ, Scranton M, Ekau W, Peña A, Dewitte B, Oguz T, Monterio PMS, Urban E, Rabalais NN, Ittekkot V, Kemp WM, Ulloa O, Elmgren R, Escobar-Briones E, Van der Plas AK (2010) Natural and human-induced hypoxia and consequences for coastal areas: synthesis and future development. Biogeosciences 7: 1443-1467. 